\title{
MODERN TRENDS IN PRODUCTION OF MILK ${ }^{1}$
}

\author{
Ljiljana Sretenović, M. M. Petrović, S. Aleksić, Dušica Ostojić, Gordana Marinkov²
}

Contents: In order to provide high milk production and ensure good reproduction in diary cows it is necessary to carefully evaluate entire production cycle and it can be said with certainty that there is period of 100 days very important for future production. This so called transitional or $» 100$ days of contract« period includes 30 days before and 70 days after calving. If during this period methods of modern technology of nutrition and breeding are applied the birth of healthy calf can be expected and cow who remains healthy during this transitional period, culmination - peak in milk production, controlled weight loss, high fertility in first insemination, etc. Realization of such success is closely related not only to nutrition but also to drying off and treatment of cows until the first insemination.

In this paper a review of the effect of certain nutrition factors on improvement of production and reproduction performances of high yielding cows is presented which leads to economical efficiency in high production of milk.

Key words: high yielding cows, nutrition, modern norms, drying off

\section{Introduction}

Idea of preparation and special care of cows in dry off period is different from traditional understanding that this is period of rest. It is known that the most important part of every work is the start, so dry off period or last 30 days of gravidity represent beginning of new lactation in which cow should be prepared for calving. Although pregnant cows do not produce milk they are metabolically active as well as reproductive in initiation of the new growth of mammary gland. Since needs for storing of energy and protein in uterus and fetus increase, simultaneously development of mammary gland occurs and lactation starts. In short, considerable increase in metabolism occurs during these 30 days of gravidity and therefore it is necessary to make adequate nutrition plan.

Period of 3-4 weeks before and period after calving represent the most traumatic period in annual cycle of dairy cows. It is also from the physiological and nutritive aspect stressful, characterized by reduced food consumption (Olsson, 1996; Murphy, 1999), whereas the need for nutritive matters which will provide the growth of fetus and initiate the synthesis of milk increases.

Beside great changes in metabolism also dramatic changes in hormonal status as preparation for calving occur and this is directly related to changes in food consumption. Reduced food consumption is especially distinct in last two weeks before calving.

Consumption of dry matter is reduced by 30 to $40 \%$ or from $2 \%$ to $1,5 \%$ of body mass of the animal. Reduced consumption of food results in negative energy status and mobilization of fat and proteins. Considerable reduction in food consumption poses on animal risk of numerous metabolic diseases. In order to avoid mentioned problems it is important to balance according to modern norms nutritive matters, that is content of total and degradable protein, energy as well as macro and micro elements and vitamins.

\section{Evaluation of the body condition of cows}

Evaluation of body condition of cows is reliable tool for evaluation of energy status. Introduction of evaluation of body condition at the end of current lactation and in dry off period is carried out in order to enable maximum consumption of dry matter and reduction of negative balance of energy in early post partum period to the least possible. Diets in this period should have energy density enabling optimum condition (mark for body condition 3.5-3.75) in dry off period and partus, in evaluation system where marks are from 1 to 5 . Loss of body condition is not desired in dry off period since cows become skinny (especially if body

1 Review paper supported by the Ministry of Science and Environment Protection, Project no. TR6858 - Revijalni rad je finansiran od strane Ministarstva za nauku i zaštitu životne sredine Projektom broj: TR6858

2 Dr Ljiljana Sretenović, scientific counselor, dr Milan Petrović, scientific counselor, dr Stevica Aleksić, scientific counselor, grad. eng. Dušica Ostojić, research trainee, grad chem. Gordana Marinkov, Institute for Animal Husbandry, Belgrade-Zemun. 
condition was 2.75) and they loose body reserves necessary for production of milk in early lactation. But, cows which were over fattened showed syndrome of »fat cows« which is related to metabolic disorders, infectious and reproductive disorders. It was established that there is close relation between loss of body condition after calving (indicating negative balance of energy) and problems in reproduction compared to status of body condition immediately before calving. However, loss of body condition or in other words of body mass after calving coincides with lower ovarian activity and prolonged service period. In case of cows with negative energy balance absence of oestrus in the first nine weeks of lactation was often registered, therefore early establishing of ovarian activity after calving is important in order to ensure optimum reproductive performance. Providing of optimal consumption of dry matter immediately before and after partus is of great importance in regard to avoiding of great losses in body condition after calving.

\section{Importance of correct standardization of diets in regard to content of total and degradable protein}

By creation of genetic predisposition for increased production of milk nutrition of high yielding cows becomes increasingly complex problem and main limiting factor. This relates first of all to standardization of proteins, total (TP) and proteins which are non degradable at the level of reticulum (UIP). Numerous researchers have indicated that every decrease of nondegradable protein fraction from stated recommendations (NRC 2001) causes decrease in production of milk, however their increase doesn't influence the adequate increase in production. Similar situation is with quantity of total protein where their quantity is limited and further increase of total proteins has no justification. This was established by numerous researchers among which are Holter (1993) and Higgibotham et al. (1989), Nianogo et al. (1991), Pavličević et al., (1995). Considering that protein feeds most frequently represent the most expensive component in diets for high yielding cows the knowledge of these issues contributes to more rational consumption of proteins and leads to better economical efficiency of milk production. Sretenovic et al. (1997) investigated the same topic in two different trials: in the first trial the effect of three different levels of total proteins in DM (16, 18 and $20 \%$ ) of diet was investigated during first 100 days of lactation and in the second trial within the diet with $18 \%$ of total proteins in DM which was established as the most optimal, the effect of three different ratios of non degradable and degradable proteins - 29:71;37:63 and 45:55\% on production of milk and reproduction was investigated. As results of nutrition treatments, cows fed diets containing $18 \%$ of total proteins produced the highest quantity of milk $(35,8$ or $33.05 \mathrm{~kg} 4 \% \mathrm{FCM}), \mathrm{P}<0.05$, whereas in the second trial the highest production of milk ( 35.48 or $33.12 \mathrm{~kg} 4 \% \mathrm{FCM}$ ) was registered in case of cows fed diets containing $37 \%$ of non degradable proteins. Quantity of total proteins had no effect on change of reproductive parameters. Best reproductive parameters were established in cows fed diets containing $37 \%$ of non degradable proteins: service period 97.2 days $(\mathrm{P}<0.05)$, insemination index 1.80; conception after first insemination 41.70 and urea concentration of $6.95 \mathrm{mmmol} / \mathrm{l}$. Obtained results are in accordance with results obtained by Howard et al. (1987) on treatments with 15 and $20 \%$ of total proteins (TP) in DM of diet, however the relation between the quantity of total proteins and reproduction was not established in this research. Also, Kaim et al. (1983) established no differences in the period before first oestrus between treatments with higher and lower protein level (16 and 20\% TP) but diets were balanced in regard to non degradable proteins (37\%). Scientists used degradability of protein in rumen to attempt to explain variations in conception. They concluded that by increase of share of degradable proteins (DIP) in diet \% of conception decreased. According to their evaluation every increase of DIP in diet by $0.1 \mathrm{~kg}$ over the need of micro organism conception is reduced by $3 \%$. This occurrence was explained through presence of $\mathrm{NH} 3$, urea and other nitrogen units created in the process and their negative effect in body tissues. This was especially apparent if such diet didn't contain adequate content of energy.

As source of non degradable proteins today most often thermally treated soy bean is used, also cotton grain, corn gluten, brewer's dried grains, meat or bone meal, blood meal, meal from feathers, etc. It is considered that these feeds need to be components of diets for high yielding cows whose daily production exceeds $5 \%$ of their body mass. 
Importance of correct standardization of diets in regard to energy content

It is estimated that $80 \%$ of dairy cows have negative energy balance in early lactation since energy needs for production of milk cannot be satisfied by consumption of food. Problems in reproduction of cows can be related to degree of negative energy balance in early lactation. Its importance is emphasized in regard to quality of egg cells and embryos in reproduction. Insufficient quantities of energy in process of multiplying of micro organisms of rumen limits the production of evaporable fatty acids and synthesis of microbe proteins which is reflected on quantity of produced milk.

However, all of the mentioned problems can be solve through use of knowledge of needs of high yielding cows, modern standards in nutrition based on energy balance, physiology of lipid digestion as well as knowledge of modern technological procedures of fat and oil protection and with use of feeds with high energy concentration. Providing larger quantities of concentrates doesn't solve the problem and additionally it disrupts the process of digestion (Keady at al., 2001). Adding of fat to diets for cows influences increased total quantity of consumed energy and conditions for high production of milk are created.

Practical recommendations for use of fat in diets for high yielding cows indicate that total fat should be limited to $7-8 \%$ in dry matter of diet. It should be taken into account that one third is provided from feeds contained in diet, one third from oleaceous plants (soy bean, sunflower grain, corn germs, etc.) and one third from protected fats (Sretenovićeva et al., 1997., Stoićević et al., 1994.)

As a result of non balanced diet in regard to energy, at the beginning of lactation metabolic disorders occur which have negative consequences on production, reproduction and health of animals. For instance, ketosis is frequent disease caused by inadequate and incorrect nutrition during dry off period and immediately after partus and especially in most productive cows (Markusfeld, 1993). Prevention of this metabolic disorder can be achieved using glucogenic matters. In case of heads of cattle where there is predisposition it is necessary to introduce the glucogene additives 15 to 20 days prior to calving in order to avoid the problems. Results of the trial carried out by Stoićević et al. (1990) in which $0.5 \mathrm{~kg}$ of glucogenic additive (propylene glycol) was included in diet for high yielding cows in the period of two weeks before and eight weeks after calving indicate positive effect of added energy source on production of $4 \% \mathrm{FCM}$ by $5 \%$ as well as better reproduction parameters (higher conception rate, lower insemination index and shorter service period. Also, based on content of major metabolites in blood serum of cows it can be concluded that although there were more animals with positive keto test in the group $(8: 2)$ they were within physiologically optimal limits. Based on research results it can be concluded that use of glucogene additive two weeks before and eight weeks after calving has positive effect on prevention of metabolic disorders (ketosis) and in animal with predisposition for this disease no clinical signs are demonstrated.

\section{Effect of certain microelements and vitamins on production and reproduction performance of high yielding cows}

Correct standardization of diets in regard to protein and energy contents as two major nutrition parameters has same importance as standardization of diet in regard to content of certain minerals and vitamins which are known to have essential role in animal organism. The effect of addition of synthetic beta carotene in combination with vitamins $\mathrm{A}$ and $\mathrm{E}$ to diets for high yielding cows determined by author Sretenović et al. (1999) will be presented in this paper.

The effect of beta carotene is even more important since it is known that beside the fact that it is provitamin of the vitamin A it also has completely independent role in the organism. In order to determine in which physiological stage it would be most efficient to initiate administration of this important provitamin, three groups of cows were formed ( $3 \times 2)$, cows receiving beta carotene in dry off period, immediately after calving and in late lactation or cows experiencing reproduction problems - still no conception on $150^{\text {th }}$ day of lactation. Insemination index in dry cows as well as cows with reproduction problems who received beta carotene was lower compared to control $(1.94: 2.94$ and $2.25: 2.75)$. Service period in trial groups of cows who have just calved and those experiencing reproduction problems was shorter (112.5: 102.9 and 162.9:189.3 days). Effect of beta carotene on intensity of oestrus and function of corpus luteum was estimated through determination of progesterone level in blood on $7^{\text {th }}, 14^{\text {th }}$ and $20^{\text {th }}$ day after oestrus and it was established that this level was higher in cows of trial groups.

Adding of beta carotene to diets for high yielding cows in all investigated treatments compared to control has caused increase of quantity of milk by $7.75 \%(\mathrm{P}<0.05)$. Based on presented results it can be 
concluded incontrovertibly that introduction of beta carotene into diets for high yielding cows in winter period has full justification and that it is best to intervene in dry period. Addition of beta carotene is justifiable in high yielding cows in industrial breeding conditions where cows are tied inside stables and during winter liver depots are emptied almost entirely. During summer nutrition sufficient quantity is consumed through green feeds therefore intervention with additional beta carotene is not justified (Sretenović et al., 1989, Sretenović et al., 2004). Similar results were obtained by Arechiga et al. (1998) who have concluded based on results from three trials that cows who consumed $400 \mathrm{mg}$ of beta carotene daily produced more milk by $6-11 \%$. Conception rate increased from 21.1 to $35.4 \%$ in period of 120 days from calving in cows who consumed beta carotene during period of 90 days.

Depending on the composition of feed in main diet cows should receive between 200 and $400 \mathrm{mg}$ beta carotene daily starting from 14 days before calving and continuing until new pregnancy is established.

Beside beta carotene also introduction of organically bound selenium is important for improvement of production and reproduction performances in dairy cows. Many researchers have established that addition of organic selenium through diets can increase its concentration in milk by 4 to 5 times. Higher concentration of selenium in milk is result of better retention of organic selenium compared to inorganic in form of selenite, since selenium in organic form of selenium methionine is incorporated in all body proteins. Mammary gland extracts large quantities of methionine for building of milk protein. Increase of methionine concentration in milk is caused by selenium yeast used in nutrition and constant incorporation of selenium methionine in casein during milk synthesis.

When selenite is taken major part of absorbed selenium enters the inorganic pool and probably is used for synthesis in form of selenium cystein and incorporated into specific selenium proteins, but not in proteins such as casein. Higher concentration of selenium in dairy products means more selenium in human nutrition and organism which has positive implications since it is known that selenium is essential micro element with powerful antioxidant action. Milk enriched with selenium is considered as functional food which beside its nutritive traits also has preventive effect in numerous human diseases.

In order to obtain high quality cow milk two key moments are significant: adequate nutrition and health status of mammary gland, which can be satisfied through regular introduction of selenium in organic form. Recommendations for daily quantity of selenium are 0.3 and $0.1 \mathrm{mg} / \mathrm{kg}$ of dry matter for dairy and fattening cattle. In research by Sretenović et al. (1999) the effect of addition of selenium Se and other micro elements compared to inorganic form with share of $30: 70 \%$ on production and reproduction traits of high yielding cows was investigated. Research results indicate that quantity of milk with $4 \% \mathrm{~mm}$ in trial group was higher by $1.43 \mathrm{~kg}$ or $7.22 \%$ ( $<<0.05)$. Somatic cell count was reduced in trial group compared to control by $13.78 \%$. Pregnancy rate in trial group was higher by $10.34 \%$ in comparison to control and was 64 and $58 \%$. In the paper by same authors Sretenović et al. (1994) effects of the organic selenium in form of selenium methionine were compared with inorganic selenium in diets for high yielding cows. Administration of selenium started 15 days before calving and lasted 100 days of lactation. In trial group of cows milk quantity increased by $0.83 \mathrm{~kg}$ or $3.5 \%(\mathrm{P}<0.05)$, and content of selenium in blood increased by $2.1 \%$. These results show the justification of introduction of selenium in organic form into diets for cows since this is the most natural way to introduce selenium into human organism. Obtained results are in accordance with results obtained by Adamović et al. (1997). Positive effect of addition of selenium on occurrence of clinical mastitis is probably related to the effect of selenium on neutrophyles and other immune cells. In research by Bolanda et al. (2002) addition of selenium in combination with other micro elements to diets for cows caused reduction of somatic cell count by $40 \%$. In the second trial by same author where cows used in trial had unified somatic cell count, average milk yield was by $1.08 \mathrm{~kg} /$ day higher in trial group in relation to control $(\mathrm{P}<0.05)$, and somatic cell count lower by $38 \%$. In research by Popović and Marina Vukić Vraneš (1998) supplementation of organic selenium (Sel-Plex 50) in combination with live yeast cells and organically bound Zink in diets for cows for period of 100 days it was established that quantity of milk increased by $1,71 \mathrm{~kg}$ or $7.6 \%$, of milk fat by $6.14 \mathrm{~kg}$ or $7.8 \%$, and of protein by $7.63 \mathrm{~kg}$ or $10.42 \%(\mathrm{P}<0.05)$. In the same trial in first calving cows considerable increase of protein from 3.32 to $3.46(\mathrm{P}<0.05)$ was determined. In cows in lactation higher percentage of mastitis was registered in control $(9 \%)$ compared to trial group (4.6\%) which can be partially attributed to the effect of treatment.

It was thought for long time that retained placenta and infections of the reproduction tract are exclusively consequence of malnutrition - nutrition deficits. However, researchers of the Ohio University 
have indicated the direct connection between selenium, vitamin E and retained placenta, so many producers have reacted and introduced mentioned elements in nutrition of dry cows. Optimal balance of diet in regard to content of vitamin and minerals is also very important objective in this transitional period.

\section{SAVREMENI TRENDOVI U PROIZVODNJI MLEKA}

Ljiljana Sretenović, M. M. Petrović, S. Aleksić, Dušica Ostojić, Gordana Marinkov

$$
\text { Rezime }
$$

Primena strogo kontrolisanih obroka koji su izbalansirani po najsavremenijim normativima u svim ishrambenim pokazateljima kako u fazi zasušenja tako i u ranoj laktaciji osnovna je predpostavka koja garantuje dobre proizvodne, reproduktivne i zdravstvene performanse visokomlečnih krava u budućoj laktaciji. Na ovaj način moguće je izbeći većinu problema koji se generiraju baš u ovom najosetljivijem periodu što jednovremeno obezbeđuje i najveće racionalizacije u visokoj proizvodnji mleka kao najosetljivijoj i najsloženijoj proizvodnji u govedarstvu.

\section{Literature}

1. ADAMOVIĆ M., JOVANOVIĆ R., STOIĆEVIĆ LJ., RADOVANOVIĆ M., SRETENOVIĆ LJILJANA, PAVLIČEVIC A., VUKIC VRANEŠ MARINA.(1997): Rezultati korišćenja organski vezanih mikroelemenata u ishrani goveda. Simpozijum "Tehnologija stočne hrane”, Tara,, 49-65.

2. ARECHIGA F., VAZQUEZ-FLORES S., ORTIZ O., HERNANDEZ-CERON J., PORRAS A., MC DOWELL R., HANSEN, J.(1998) : Effect of injection of beta-carotene or vitamin E and selenium on fertility of lactating dairy cows. Theriogenology. 50, 65-76.

3. BOLAND, M.(2002): Alltech's 16 th Annual European, Middle Eastern and African Lecture Tour. 45-53.

4. HOWARD, J., ALSEN, P., ADAMS, D., BUSH, J.(1987): Influence of dairy protein on reproductive performance of dairy cows. Journal of Dairy Science, 70, 1563-1571.

5. HIGGINBOTHAM E., TORABI M., HUBER T.(1989). : Influence of dietary protein concentration and degradability on performance of lactating cows during hot environmental temperatures, Journal of Dairy Science, 72, 2554-2564.

6. HOLTER B., HAYES H., KRIERSTEAD N., WHITENOUSE, J. (1993): Protein-fat bypass supplement for lactating dairy cows. Journal of Dairy Science, 76, 1342-1352.

7. KAIM, M., FOLMAN, Y., NEUMARK H. (1983): The effect of protein intake and lactation number on post-partum body weight loss and reproductive performance of dairy cows. Anim. Prod., 37, 229.

8. KEADY T.W.J., MAYNE C.S., FITZPATRICK D.A., MC COY M.A.(2001): Effect of concentrate feed level in late gestation on subsequent milk yield, milk composition and fertility of dairy cows. Journal of Dairy Science, 84: 1468-1479.

9. MARKUSFELD, O.(1993): Parturition disease complex of the high-yielding dairy cow. Acta Vet Scand. Suppl.89:9.

10. MURPHY, J.(1999).: Effect of dry period protein feeding on post-partum milk production and composition. Livestock Production Science, 57, 169-179.

11. NIANOGO J., AMOS E., FROETSCHEL A., KEERY M.(1991): Dietary feat protein degradability and calving season: effect on nutrient use and performance of early lactation cows. Journal of Fairy Science, $74,2243-2255$.

12. NRC (2001): $7^{\text {th }}$ edition of the Nutrient Requirement of Dairy Cattle. Nacional Academy Pres. Washington, 2001.

13. OLSSON, G.(1996): Effects of feeding strategy before calving on dairy cow performance. Agrari 18, Swedish University of Agricultural Science, Uppsala, Sweden.

14. PAVLIČEVIĆ A., GRUBIĆ G., JOVANOVIĆ R., ADAMOVIĆ M., SRETENOVIĆ LJILJANA, STOIĆEVIĆ Lj.(1995): Uticaj tehnologije ishrane na produkciju visokomlečnih krava u prvih 100 dana laktacije. IX Savetovanje agronoma i tehnologa, Zbornik radova, HK “Agroekonomik”, Beograd, 96-101. 
15. POPOVIĆ Z., MARINA VUKIĆ VRANEŠ.(1998): Organski vezani mikroelementi i žive ćelije kvasca u ishrani muznih krava. Farmer, br.12, 9.

16. SRETENOVIĆ LJILJANA (2004):Noviji aspekti uticaja ishrane na količinu i sastav mleka. Simpozijum » Mleko i proizvodi od mleka stanje i perspektive«, Zlatibor, 63-73.

17. SRETENOVIĆ LJILJANA, ADAMOVIĆ M., JOVANOVIĆ R., STOIĆEVIĆ LJ., GRUBIĆ G., VESNA NIKOLIĆ. (1994):: Ispitivanje organski vezanog selena u obrocima visokomlečnih krava u ranoj laktaciji. VII Savetovanje veterinara Srbije, Zbornik kratkih radova, Zlatibor,.str. 52.

18. SRETENOVIĆ LJILJANA, GRUBIĆ G., ADAMOVIĆ M., MILOŠEVIĆ M., STOIĆEVIĆ LJ., JOVANOVIĆ R.(1997): The maize germs in high producing dairy cows rations. Review of Research Work at the Faculty of Agriculture, 211-219.

19. SRETENOVIĆ LJILJANA, JOVANOVIĆ R., ADAMOVIĆ M., MILOŠEVIĆ M.(1999): Organically tied selenium in high yielding cows nutrition. Biotehnologija u stočarstvu, 69-76.

20. SRETENOVIĆ LJILJANA, JOVANOVIĆ R., ADAMOVIĆ M., MILOŠEVIĆ M.(1999): The influence of beta carotene on reproductive and production traits in high yielding dairy cows. The 5th International Symposium "New Trends in Breeding Farm Animals". Biotehnologija u stočarstvu, 77-87.

21. SRETENOVIĆ LJILJANA, JOVANOVIĆ R., ADAMOVIĆ M., STOIĆEVIĆ LJ., GRUBIĆ G., NEGOVANOVIĆ D(1997).: Uticaj razlišite količine ukupnih i nerazgradivih proteina u obrocima krava na proizvodnju mleka i reprodukciju. I Jugoslovenski kongres o stočarstvu, Biotehnologija 3-4.

22. SRETENOVIĆ LJILJANA, MARINA VUKIĆ-VRANEŠ(2004): Efekti korišćenja organski vezanog selena u proizvodnji mleka. Simpozijum » Mleko i proizvodi od mleka stanje i perspektive« Zlatibor, 198-199.

23. SRETENOVIĆ LJILJANA, MILOŠEVIĆ M., ADAMOVIĆ M., STOIĆEVIĆ Lj. (1989).: Značaj i uloga betakarotina kod goveda. Nauka u praksi, Beograd, br. 1, 59-68.

24. STOIĆEVIĆ LJ., JOVANOVIĆ R., ADAMOVIĆ M., SRETENOVIĆ LJILJANA, GRUBIĆ G.(1996): Efekti korišćenja glukogenog dodatka u preveniranju ketoze visokomlečnih krava. IX Savetovanje veterinara Srbije, Zlatibor.

25. STOIĆEVIĆ LJ., ZEREMSKI D., ADAMOVIĆ M., NIKOLIĆ P., SRETENOVIĆ LJILJANA, JOVANOVIĆ R., AŠKOVIĆ, P. (1994): Sojino ulje i goveđi loj kao dodatni izvor energije u obrocima visokoproizvodnih krava. VIII Savetovanje agronoma i tehnologa. Zbornik radova, HK "Agroekonomik", Smederevo, 72-77. 